KONSTRUKTIVISME, Vol. 10, No. 2, Juli 2018

p-ISSN: 1979-9438; e-ISSN: 2442-2355

FKIP Universitas Islam Balitar, Blitar

Http://konstruktivisme.unisbablitar.ejournal.web.id; Email: konunisba@gmail.com

\title{
TEKNIK MPN COLIFORM \\ SEBAGAI REFERENSI MATA KULIAH MIKROBIOLOGI
}

\author{
Marinda Sari Sofiyana ${ }^{1}$, Eva Nurul Malahayati ${ }^{2}$ \\ Dosen Program Studi Pendidikan Biologi, Universitas Islam Balitar \\ Email: sarisofiyana@gmail.com ${ }^{1}$, eva.malahayati@yahoo.co.id ${ }^{2}$
}

\section{ABSTRAK:}

Tujuan penelitian ini adalah mengembangkan buku referensi berbasis riset menggunakan teknik MPN coliform. Pengembangan ini menggunakan model pengembangan Hannafin dan Peck yang terdiri dari 3 tahap, yaitu (1) Need Assesment (Analisis Keperluan); (2) Design (Desain); (3) Develop and Implement (Pengembangan dan Implementasi. Model pengembangan ini merupakan model yang berorientasi pada produk. Tahap pertama diawali dengan analisis kebutuhan, perancangan produk, pembuatan produk, dan validasi produk. Instrumen yang digunakan adalah angket dan pedoman wawancara. Data dianalisis secara deskriptif. Berdasarkan hasil analisis menunjukkan referensi yang disusun telah memenuhi syarat kelayakan. Tingkat kelayakan uji terbatas perorangan mahasiswa diperoleh sebesar $80 \%$ dengan kategori valid, uji kelayakan dari ahli media diperoleh sebesar $88.25 \%$ dengan kategori valid, dan uji kelayakan sajian materi sebesar $88,25 \%$ dengan kategori valid dan layak untuk digunakan.

Kata Kunci: MPN Coliform, Referensi, Mikrobiologi

\section{ABSTRACT:}

The aim of the research was to develop a research-based reference book using the coliform MPN technique.The development uses Hannafin development model which consists of three phases, they are (1) Need Assessment (Analysis of Needs); (2) Design (Design); (3) Develop and Implement (Development and Implementation. This development model is a product-oriented model. The first stage begins with needs analysis, product design, product manufacture, and product validation. The instruments used are questionnaires and interview guidelines. Data are analyzed descriptively. Based on the result of the analysis, it shows that the compiled references have met the eligibility requirements. The level of feasibility of the limited test of individual students is obtained at $80 \%$ with a valid category, the feasibility test from a media expert is obtained 
Marinda Sari Sofiyana ${ }^{1}$, Eva Nurul Malahayati ${ }^{2}$. 2018. Teknik MPN Coliform

sebagai Referensi Mata Kuliah Mikrobiologi. Konstruktivisme, 10 (2): 248-255

at $88.25 \%$ with a valid category, and the feasibility test for material content is $88.25 \%$ with a valid and feasible category to apply.

Keywords: MPN Coliform, References, Microbiology

\section{PENDAHULUAN}

Pendidikan merupakan usaha sadar dan terencana untuk meningkatkan taraf hidup. Pendidikan tidak hanya untuk menambah pengetahuan, tetapi juga proses pembentukan sikap dan keterampilan dengan menjadikan mahasiswa aktif dan berkembang mengembangkan potensi keilmuan dan kepribadian. Ketercapaian Kajian Keilmuan dan Pengetahuan (KKP) berdasarkan parameter Kerangka Kualifikasi Nasional Indonesia (KKNI) yang telah dirancang oleh Badan Standart Nasional Pendidikan (BSNP), pendidikan biologi memerlukan pengaplikasian konsep dan prinsip dedaktikpedagogis biologi serta keilmuan biologi untuk menguasai konsep teoritis dan prinsip-prinsip keilmuan biologi, perencanaan pengelolaan, keterampilan dalam melakukan pelaksanaan evaluasi dan pengembangan pembelajaran biologi serta menguasai Pedagogical Content Knowledge (PCK) serta mampu mengidentifikasi permasalahan pembelajaran dan memecahkannya menggunakan metode ilmiah dalam pendidikan biologi (Kurikulum Pendidikan Biologi, UNISBA).

Mata kuliah mikrobiologi merupakan mata kuliah wajib 3 sks yang diberikan kepada mahasiswa semester $\mathrm{V}$ pendidikan biologi. Materi dalam perkuliahan mikrobiologi membahas tentang mikroba dan aplikasinya dalam berbagai bidang kehidupan yang bertujuan untuk memberikan wawasan pengetahuan dan keterampilan-keterampilan dasar laboratorium. Untuk menunjang pemahaman konsep dan melatih kerja ilmiah dalam dunia mikroba serta peranan mikroba dalam berbagai bidang kehidupan, perkuliahan ini didukung dengan kegiatan praktikum di laboratorium. Salah satu kegiatan praktikum pada mata kuliah mikrobiologi adalah studi pemantauan lingkungan menggunakan teknik MPN coliform. Teknik MPN telah menjadi salah satu metode standard untuk menghitung jenis Coliform, Fecal Coliform, E. coli dan S. aureus.

Permasalahan yang ditemukan peneliti dari kegiatan observasi di kelas adalah belum ada buku referensi sebagai pendamping kegiatan praktikum mata kuliah mikrobiologi di laboratorium. Selama ini yang sudah dikembangkan hanyalah buku petunjuk praktikum yang hanya berisi langkahlangkah melakukan praktikum tanpa ada dasar-dasar teori. Akibatnya mahasiswa kesulitan menemukan teori yang mendukung hasil praktikum karena tidak memiliki referensi yang sesuai dengan praktikum yang telah dilakukan. Kegiatan praktikum sangat bermanfaat bagi mahasiswa karena 
Marinda Sari Sofiyana ${ }^{1}$, Eva Nurul Malahayati ${ }^{2}$. 2018. Teknik MPN Coliform sebagai Referensi Mata Kuliah Mikrobiologi. Konstruktivisme, 10 (2): 248-255

mahasiswa mendapatkan pengalaman langsung. Mahasiswa yang mengalami, merasakan sendiri segala sesuatu yang berhubungan dengan objek yang dipelajarinya akan kecenderungan hasil belajar yang diperoleh mahasiswa menjadi kongkrit (Sanjaya 2007).

Berdasarkan hasil analisis kebutuhan dan paparan di atas, maka pengembangan buku referensi berbasis hasil penelitian pada matakuliah Mikrobiologi perlu ditempuh. Buku referensi yang dikembangkan tersebut merupakan buku penunjang petunjuk praktikum Mikrobiologi, sehingga buku referensi tersebut mampu menyajikan sumber informasi yang lain selain pada referensi yang telah ada. Materi dikemas secara menarik disertai cara sampling, cara identifikasi, dan hasil-hasil penelitian yang dilakukan serta ditambah informasi lain yang relevan dari pustaka lain.

\section{METODE PENELITIAN}

Penelitian ini merupakan penelitian pengembangan buku ajar berbasis penelitian uji kualitas air sumur warga di TPA Sampah Ngegong Kota Blitar Penelitian dilaksanakan dua tahap, tahap pertama pengembangan produk buku ajar dilaksanakan di Universitas Islam Balitar pada bulan April-Juni 2018, selanjutnya dilanjutkan uji implementasi kelayakan produk dilaksanakan di Prodi Pendidikan Biologi S1 Universitas Islam Balitar pada bulan Agustus 2016.

Uji coba dilakukan untuk mengetahui tingkat validasi dan daya tarik produk buku ajar. Tingkat validitas dan daya tarik produk diketahui melalui beberapa tahap, yaitu uji coba ahli materi mikrobiologi untuk menilai isi referensi, uji coba ahli media pembelajaran untuk menilai pengembangan, dan uji coba kelompok terbatas untuk melihat keterbacaan dan daya tarik buku.

Validasi uji ahli materi ditujukan kepada dosen pengampu matakuliah mikrobiologi di prodi Pendidikan biologi Universitas Islam Balitar. Validasi uji ahli media ditujukan kepada dosen Teknologi Pembelajaran ahli media pembelajaran, dan uji keterbacaan dan daya tarik buku ditujukan kepada mahasiswa prodi pendidikan Biologi yang sedang menempuh matakuliah Mikrobiologi.

Analisis data dilakukan dengan cara deskriptif kualitatif. Teknik analisis data ini digunakan dengan mengelompokkan informasi-informasi dari data kualitatif yang berupa tanggapan dan saran

perbaikan dari validasi ahli materi dan validasi ahli media. Analisis skor yang terkumpul dari lembar validasi bertujuan untuk mendapatkan gambaran tentang bahan ajar yang dikembangkan. Setelah lembar validasi terkumpul, kemudian dihitung persentase dari tiap-tiap butir pertanyaan pada lembar validasi tersebut dengan persamaan sebagai berikut.

$$
\mathrm{K}=\mathrm{FN} \times \mathrm{I} \times \mathrm{R} \times 100 \%
$$


Marinda Sari Sofiyana ${ }^{1}$, Eva Nurul Malahayati ${ }^{2}$. 2018. Teknik MPN Coliform sebagai Referensi Mata Kuliah Mikrobiologi. Konstruktivisme, 10 (2): 248-255

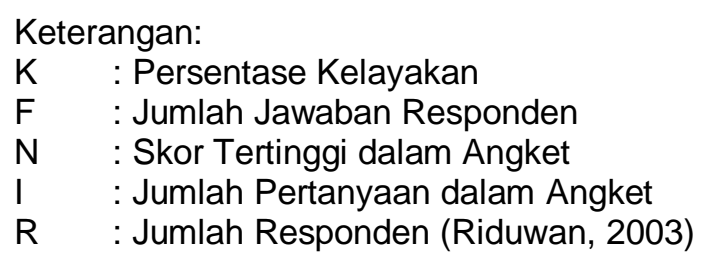

Penafsiran dan penyimpulan hasil sesuai dengan kriteria kategori penilaian ideal dengan ketentuan yang terdapat pada Tabel 1 sebagai berikut.

Tabel 1 Kriteria persentase respon validator (diadaptasi dari Riduwan 2003)

\begin{tabular}{lll}
\hline Skor & Keterangan & Keputusan Uji \\
\hline $0 \%-20 \%$ & Sangat Kurang Valid & Tidak layak dan perlu revisi besar \\
$21 \%-40 \%$ & Kurang Valid & Kurang layak dan perlu revisi besar \\
$41 \%-60 \%$ & Cukup Valid & Cukup layak dan perlu revisi besar \\
$61 \%-80 \%$ & Valid & Layak namun tetap dilakukan revisi kecil \\
$81 \%-100 \%$ & Sangat Valid & $\begin{array}{l}\text { Sangat layak dan tidak revisi jika } \\
\text { mencapai } 100 \%\end{array}$ \\
\hline
\end{tabular}

\section{HASIL DAN PEMBAHASAN}

Pengembangan buku ajar ini menggunakan model pengembangan Hannafin dan Peck, yang terdiri atas 3 tahap, yaitu (1) Need Assessment (Fase Analisis Keperluan), (2) Design (Fase Desain), dan (3) Develop/Implement (Fase Pengembangan dan Implementasi). Model pengembangan ini merupakan model desain pembelajaran yang berorientasi pada produk (Afandi \& Badarudin 2011). Hasil dari setiap tahapan pengembangan yang sudah dilakukan diuraikan sebagai berikut.

a. Analisis

Hasil analisis kebutuhan meliputi sumber belajar, metode pembelajaran dan SKS pada prodi Pendidikan Biologi telah disajikan dan diuraikan pada latar belakang masalah.

b. Desain dan Pengembangan

Perancangan draft buku yang dilakukan pada tahap desain direalisasikan pada tahap pengembangan yang telah disesuaikan dengan analisis kebutuhan kondisi mahasiswa.

c. Implementasi

Tahap implementasi merupakan tahap untuk uji coba produk. Hasil uji coba produk pengembangan sebagai berikut. Pertama, spesifikasi Produk yang dihasilkan pada buku ajar berbasis penelitian yang telah dikembangkan terdiri dari 3 topik utama. Topik pertama adalah Metode MPN (Most Probable Number) merupakan metode enumerasi mikroorganise. Topik kedua menjelaskan metode MPN coliform dideskripsikan dalam SNI 01-2332.1-2006. Terakhir, metode MPN dapat diaplikasikan langsung dalam studi kualifikasi 
Marinda Sari Sofiyana ${ }^{1}$, Eva Nurul Malahayati ${ }^{2}$. 2018. Teknik MPN Coliform sebagai Referensi Mata Kuliah Mikrobiologi. Konstruktivisme, 10 (2): 248-255

media. Penyajian data kuantitatif dari uji coba ahli materi disajikan pada Tabel 2 dan Tabel 3.

Tabel $2 \quad$ Peyajian data kuantitatif dari hasil uji coba ahli materi

\begin{tabular}{clcc}
\hline No & Aspek penilaian & Skor Rata-rata (\%) & Kualifikasi \\
\hline 1 & Enumerasi MPN Coliform & 78 & Valid \\
2 & Kualifikasi MPN Coliform & 80 & Valid \\
3 & Validasi MPN Coliform & 82 & Valid \\
& Rata tata skor & 80 & Valid \\
\hline
\end{tabular}

Tabel 2 menunjukkan bahwa peneliaian pada bab pertama dengan Enumerasi MPN Coliform perkembangan hewan, aspek penilaian keseuaian materi dengan tujuan pembelajaran, kelengkapan komponen isi materi, kebenaran konsep materi memperoleh skor sebesar $78 \%$. Begitu juga dengan isi materi, kebenaran konsep Kualifikasi MPN Coliform dan Validasi MPN Coliform masing-masing memperoleh skor sebesar $80 \%$ dan $82 \%$. Rata-rata skor yang diperoleh adalah $80 \%$ dan dinyatakan kualifikasi valid. Melalui buku ajar berbasis penelitian yang telah dikembangkan untuk matakuliah mikrobiologi diharapkan mahasiswa mampu mendapat informasi dan pembaharuan materi serta menambah sumber referensi yang lebih dinamis. Hasil yang didapat dari validasi positif.

Analisis secara mikrobiologi melalui teknik MPN terhadap sampel bertujuan untuk mengetahui keberadaan bakteri golongan coliform dan coliform fekal dalam sampel. Tujuan kedua adalah mengetahui kualitas mikrobiologi sampel berdasarkan nilai MPN coliform dan coliform fekal (Nisa et al. 2012).

Uji Coba Ahli Media

Tabel 3. Peyajian Data Kuantitatif dari Hasil Uji Coba Ahli Media

\begin{tabular}{llcc}
\hline No & Aspek penilaian & Skor Rata-rata (\%) & Kualifikasi \\
\hline 1 & Desain Kulit Buku & 90 & Valid \\
2 & Desain Isi Buku & 88 & Valid \\
3 & Kaidah Penulisan & 90 & Valid \\
4 & Kelayakan Penyajian & 85 & Valid \\
& Rata tata skor & 88.25 & Valid \\
\hline
\end{tabular}

Tabel 4. Data kuantitatif dari hasil uji coba ahli media

\begin{tabular}{|l|l|}
\hline Validator & Kritik/Saran \\
\hline \multirow{3}{*}{ Ahli Media } & $\begin{array}{l}\text { 1. Kesesuaian pada huruf sub bab judul } \\
\text { 2. Warna di perjelas untuk judul pada tiap bab }\end{array}$ \\
& $\begin{array}{l}\text { 3. Buku teks yang dikembangkan sudah layak untuk digunakan, hanya saja } \\
\text { memerlukan perbaikan sesuai dengan saran }\end{array}$ \\
\hline
\end{tabular}

Tabel 3 menunjukkan bahwa hasil penilaian yang diperoleh dari validasi ahli media mengenai desain kulit buku mencakup desain grafis, 
Marinda Sari Sofiyana ${ }^{1}$, Eva Nurul Malahayati ${ }^{2}$. 2018. Teknik MPN Coliform sebagai Referensi Mata Kuliah Mikrobiologi. Konstruktivisme, 10 (2): 248-255

warna, dan penyajian gambar memperoleh skor sebesar $90 \%$. Desain isi buku yang telah disajikan meliputi kalimat penyusunan paragraf, tata letak judul sub bab, tipografi isi buku dan juga ilustrasi keterangan gambar yang disajikan memperoleh skor sebesar $88 \%$., Kaidah penulisan, meliputi tampilan buku, penggunaan bahasa, struktur buku, keterbacaan tulisan buku, dan etika penulisan memperoleh skor sebesar $90 \%$. kelayakan penyajian buku, meliputi penyajian depan buku (prakata, daftar isi, dan daftar gambar), bagian isi (gambar, ilustrasi, rujukan), dan bagian belakang (daftar rujukan) memperoleh skor sebesar $85 \%$.

\section{Uji Coba Perorangan}

Uji coba perorangan dilakukan setelah memperoleh masukan dari uji coba ahli materi dan ahli media. Subyek coba pada tahap ini adalah 12 mahasiswa semester 4 prodi pendidikan biologi yang sedang menempuh matakuliah mikrobiologi. Hasil dari uji coba ahli media disajikan pada Tabel 5 dan Tabel 6.

Tabel 5. Peyajian Data Kuantitatif dari Hasil Uji Coba Perorangan

\begin{tabular}{|l|l|c|c|}
\hline No & Aspek penilaian & Skor Rata-rata (\%) & Kualifikasi \\
\hline 1 & Kemudahan Materi & 90 & Valid \\
\hline 2 & Kemenarikan Buku & 92 & Valid \\
\hline 3 & Keterpahaman Materi & 80 & Valid \\
\hline 4 & Keterbaharuan Materi & 85 & Valid \\
\hline Rata tata skor & & 86,75 & Valid \\
\hline
\end{tabular}

Tabel 6. Data kuantitatif hasil uji coba perorangan

\begin{tabular}{|c|c|}
\hline Validator & Kritik/Saran/Komentar \\
\hline $\begin{array}{l}\text { Uji } \\
\text { Perorangan }\end{array}$ & $\begin{array}{l}\text { 1. Buku ajar berbasis penelitian sangat bagus dan sangat } \\
\text { senang menggunakan dikarenakan baru pertama kali } \\
\text { 2. Buku menjadi menarik dikarenakan menampilkan banyak } \\
\text { gambar yang mendukung teori sehngga lebih mudah } \\
\text { memahami teori. } \\
\text { 3. Isi buku sebaiknya ditambah dengan berbagai informasi link } \\
\text { untuk dapat mengakses sumber. } \\
\text { 4. Perlu adanya revisi dan koreksi ulang untuk struktur kalimat } \\
\text { antar paraggraf. } \\
\text { 5. Warna pada sub judul diganti lebih memberikan efek menarik } \\
\text { bagi pembaca }\end{array}$ \\
\hline
\end{tabular}

Tabel 5 menunjukkan bahwa hasil validasi kelompok perorangan yang telah dilakukan prodi pendidikan biologi yang sedang menempuh matakuliah mikrobiologi untuk validasi minat keterbacaan dan daya tarik buku. Aspek penilaian untuk kemudahan materi, seperti bahasa buku yang disajikan memperoleh skor sebesar $90 \%$. Kemenarikan buku yang telah disajikan, meliputi kemenarikan materi dan kemenarikan motivasi menampilkan media 
Marinda Sari Sofiyana ${ }^{1}$, Eva Nurul Malahayati ${ }^{2}$. 2018. Teknik MPN Coliform sebagai Referensi Mata Kuliah Mikrobiologi. Konstruktivisme, 10 (2): 248-255

foto dan uraian gambar memperoleh skor sebesar $92 \%$. Keterpahaman materi meliputi keterkaitan konsep materi, keterpaduan bab, dan penyampaian pesan memperoleh skor sebesar $80 \%$. Keterbaharuan materi, meliputi penemuanpenemuan baru dan juga pemantapan konsep memperoleh skor sebesar $80 \%$. Skor rata-rata keseluruhan aspek yang diperoleh untuk validasi kelompok perorangan sebesar $86,75 \%$ sehingga dikategorikan valid. Hal ini berarti materi yang disajikan mendapat respon yang cukup besar dari para mahasiswa untuk pembaharuan materi.

Mahasiswa beranggapan bahwa dengan adanya buku ajar berbasis penelitian, mendapatkan informasi mengenai hasil- hasil penelitian yang telah dilakukan yang berkaitan dengan materi yang disajikan. Hal ini sesuai dengan pernyataan Ibana (2015) dan Sofiyana (2016) yang menyatakan bahwa buku ajar berbasis penelitian dapat dipilih sebagai sarana pengembangan hasil penelitian karena bersifat fleksibel dan buku ajar yang disusun dapat bermanfaat bagi mahasiswa untuk menunjang proses pembelajaran. Oleh karena itu, informasi-informasi dari hasil penelitian akan dituangkan dalam bentuk buku ajar berbasis penelitian dengan tambahan pustaka yang relevan.

\section{SIMPULAN}

Pengembangan buku ajar berbasis penelitian yang telah dihasilkan memiliki hasil validasi yang sangat tinggi baik dari dosen ahli materi, dosen ahli pengembangan media, dan juga mahasiswa prodi pendidikan Biologi. Selain itu, mahasiswa mengaku dengan adanya referensi berbasis penelitian dapat menambah informasi mengenai hasil-hasil penelitian yang telah dilakukan berkaitan dengan materi yang disajikan.

\section{SARAN}

Dalam pemanfaatan produk ini, terdapat beberapa saran yang diberikan, di antaranya adalah sebagai berikut.

1. Referensi berbasis penelitian ini dalam pengguanaanya sebaiknya bersamaan dengan buku teks yang lain sehingga dapat saling melengkapi keterkaiatan antara satu dengan yang lainya.

2. Penggunaan referensi berbasis penelitian ini perlu dilakukan dengan alat-alat dan bahan laboratorium mikrobiologi yang lengkap dan khusus sehingga dapat menjadikan mahasiswa mampu bekerja secara langsung dan mandiri

\section{DAFTAR RUJUKAN}

Afandi M, Badarudin. 2011. Perencanaan Pembelajaran. Bandung: Alfabeta.

Clark BR. 1997. The Modern Integration of Research Activities with Teaching and Learning. Ohio: J. Higher Educ. 
Marinda Sari Sofiyana ${ }^{1}$, Eva Nurul Malahayati ${ }^{2}$. 2018. Teknik MPN Coliform sebagai Referensi Mata Kuliah Mikrobiologi. Konstruktivisme, 10 (2): 248-255

Ibana L. 2015. Mikroalga sebagai loindikator Pencemaran Perairan di Waduk Selorejo untuk Pengembangan Buku Referensi Biologi. Malang: UM Press. Kurikulum Pendidikan Biologi,

Majid A. 2007. Perencanaan Pembelajaran dan Mengembangkan Standar Kompetensi Guru. Bandung: PT Remaja Rosda Karya.

Nisa AS, Hastuti US, Witjoro A. 2012. Analisis mikrobiologi minuman teh seduhan berbeda merk berdasarkan nilai mpn coliform di Kota Malang. Universitas Negeri Surakarta: Seminar Nasional IX Pendidikan Biologi FKIP UNS.

Riduwan. 2003. Dasar-Dasar Statistika. Bandung: Alfabeta. Sadiman, A. S. 2009. Media Pendidikan: Pengertian dan Pemanfaatannya Edisi 1 Cetakan Ke-13. Jakarta: Raja Grafindo Persada.

Sanjaya W. 2007. Strategi Pembelajaran Berorientasi Standar Proses Pendidikan. Jakarta : Kencana Prenada Media Group.

Sofiyana MS, Rohman F, Saptasari M. 2016. Pengembangan buku referensi bioekologi berdasarkan kajian struktur komunitas lumut epifit di Taman Nasional Bromo Tengger Semeru. Konstruktivisme 8 (2): 117-130. 